\title{
AN INDIGENOUS SPECIES, DREISSENA POLYMORPHA (PALLAS, 1771) (MOLLUSCA, BIVALVIA), AS AN INVADER IN LAKE BÜYÜK AKGÖL
}

\author{
Naime ARSLAN *, Seval KÖKMEN-ARAS ** and Deniz MERCAN * \\ * Eskişehir Osmangazi University, Faculty of Arts and Sciences, Department of Biology, Eskişehir, \\ Turkey, P.O. Box 26480, oligo2009@gmail.com, deniss-kara@hotmail.com \\ ** Nevşehir Hacı Bektaş Veli University, Faculty of Engineering and Architecture, Department of \\ Environmental Engineering, Nevşehir, Turkey, P.O. Box. 50300, seval_kokmen@hotmail.com
}

DOI: 10.2478/trser-2018-0011

KEYWORDS: benthic macroinvertebrates, abundance, Büyük Akgöl Lake, Turkey.

\section{ABSTRACT}

The relative abundance of $D$. polymorpha and other benthic macroinvertebrates in lake Büyük Akgöl was studied in 2009, 2012 and 2014. In 2009, the macroinvertebrate fauna consisted of Gastropoda (53.4\%), Bivalvia (26.8\%), Oligochaeta (12.6\%), Chironomidae (5.9\%) and other taxonomic groups (Trichoptera, Ceratopogonidae, Ephemeroptera, Odonata, Chaoboridae, and Hirudinea) (1.04\%). After three years, Bivalvia and Oligochaeta increased (38.2\% and 15.3\%, respectively), whereas the other groups (in particular, Gastropoda and Chironomidae) were found to decrease ( $41.4 \%$ and $4.5 \%$, respectively). For the study period, the relative abundance of $D$. polymorpha increased from $19.6 \%$ (2009) to $34.8 \%$ (2014). The species has occupied various benthic habitats of lake Büyük Akgöl and continued to spread during the study period.

RÉSUMÉ: Une espèce indigène, Dreissena polymorpha (Pallas, 1771) (Mollusca, Bivalvia), envahissant le Lac Büyük Akgol.

Les abondances relatives de $D$. polymorpha et d'autres invertébrés benthiques dans le Lac Büyük Akgöl ont été étudiées en 2009, 2012 et 2014. En 2009, la faune macroinvertébrée était formée de Gastropoda (53,4\%), Bivalvia (26,8\%), Oligochaeta (12,6\%), Chironomidae (5,9\%) et d'autres groupes taxonomiques (Trichoptera, Ceratopogonidae, Ephemeroptera, Odonata, Chaoboridae, et Hirudinea) (1,04\%). Trois ans plus tard, Bivalvia et Oligochaeta ont augmenté en nombre (38,2\% et respectivement 15,3\%), pendant que d'autres groupes (particulièrement Gastropoda et Chironomidae) ont diminué en nombre $(41,4$ et respectivement 4,5\%). Durant la période de l'étude, l'abondance relative de $D$. polymorpha a augmenté de 19,6\% (2009) à 34,8\% (2014). L'espèce a occupé des différents habitats benthiques du Lac Büyük Akgöl et a continué de se répandre durant la période étudiée.

REZUMAT: O specie indigenă, Dreissena polymorpha (Pallas, 1771) (Mollusca, Bivalvia), ca invadator în Lacul Büyük Akgol.

În anii 2009, 2012 și 2014 s-au studiat abundențele relative ale D. polymorpha și ale nevertebratelor bentice în Lacul Büyük Akgöl. În 2009, fauna de macronevertebrate consta din Gastropoda (53,4\%), Bivalvia (26,8\%), Oligochaeta $(12,6 \%)$, Chironomidae $(5,9 \%)$ și alte grupe taxonomice (Trichoptera, Ceratopogonidae, Ephemeroptera, Odonata, Chaoboridae și Hirudinea) (1,04\%). Trei ani mai târziu, Bivalvia și Oligochaeta au devenit mai abundente (38,2\% și respectiv 15,3\%), pe când alte grupe (în special Gastropoda și Chironomidae) s-au restrâns $(41,4 \%$ și respectiv $4,5 \%)$. În perioada studiată, abundența relativă a $D$. polymorpha a crescut de la 19,6\% (2009) la 34,8\% (2014). Specia a ocupat diferite habitate bentice din Lacul Büyük Akgöl și a continuat să se extindă pe durata studiului. 


\section{INTRODUCTION}

The invasive alien species are considered to majorly influence biodiversity loss because of their impact and elimination of native species, and damages on local ecosystems and ecosystem structures (Pimentel et al., 2000; Luque et al., 2013; Anastasiu et al., 2017). The alien species that are considered invasive are characterised with high ability to adapt physiologically to new conditions, high genetic variability, rapid reproduction and growth, early sexual maturity, and opportunistic feeding (Ricciardi and Rasmussen, 1999; Hulme, 2009).

The zebra mussel, Dreissena polymorpha (Pallas, 1771) (Mollusca: Bivalvia: Dreissenidae), is one of the worst invaders worldwide. Its native range includes the basins of the Black Sea, the Caspian Sea and Aral Lake, and related estuaries, coastal waters, freshwater lakes, and rivers. Since the 18th century, D. polymorpha has been distributed outside its native range in Europe. It was first recorded in England in 1824 (Pollux et al., 2003) and then spread to Denmark, Sweden, Finland, Ireland, Italy and other European countries.

In Turkey, the presence of $D$. polymorpha was recorded for the first time in 1897 (Geldiay and Bilgin, 1973). Turkey is considered among the native distribution areas of this species (Daniszewski, 2015; Draszawka-Bolzan and Cyraniak, 2015; Wilas et al., 2016; Aksu et al., 2017). In the last 25 years, the species has been reported in many freshwater systems in Turkey. It has also threatened water supply security, and it can potentially be transferred to new areas where not reported before (Aksu et al., 2017).

Dreissena polymorpha is a sessile and suspension feeding organism, and when in high abundance, has the potential to negatively impact plankton and benthic communities (Ackerman et al., 2001; Minchin et al., 2002; Daunys et al., 2006). It may cause an increase or decrease in the benthic plant and algal abundance or change in the overall community structure of benthic macroinvertebrates (Griffiths, 1993; Dermott and Munawer, 1993; Stewart and Haynes, 1994; Stuckey and Moore, 1995; Botts et al., 1996). Kharchenko and Protasov (1981) examined the effect of Dreissena ssp. (D. polymorpha and D. bugensis) occurrence on diversity of benthic communities in the North-Crimean Canal, in Ukraine. Their results showed that the presence of Dreissena ssp. causes a two-fold increase in the diversity of benthic communities, as well as an increase in species richness, density, and biomass of the benthic fauna. Dusoge (1966) also found that the abundance of benthic invertebrates in Mikolajskie Lake, Poland is correlated positively with the abundance of $D$. polymorpha. In another study carried out by Afanasiev (1987), a positive correlation was found between the biomass of $D$. polymorpha and the density of some oligochaetes in a cooling-reservoir of a power plant in Ukraine.

The aims of this research were: 1) to examine the population abundance of $D$. polymorpha and other benthic macroinvertebrates (Gastropoda, Oligochaeta and Chironomidae) in lake Büyük Akgöl in 2009, 2012 and 2014 years, and 2) to determine the impact of $D$. polymorpha on the other benthic macroinvertebrate fauna in the lake. 


\section{MATERIAL AND METHODS}

\section{Study area}

Lake Büyük Akgöl is located in Sakarya Province, Marmara Region, Turkey, about four to five km far from the Black Sea coast (Fig. 1). There is a recreational area around the lake and it is occupied intensively by industrial facilities; 236 industrial facilities are found within the borders of Sakarya Province. In the past, the water from the lake was used as drinking and municipal water by Gölkent Municipality (populated by 2000 people in 1997). Today the lake is facing the dangers of pollution and destruction.

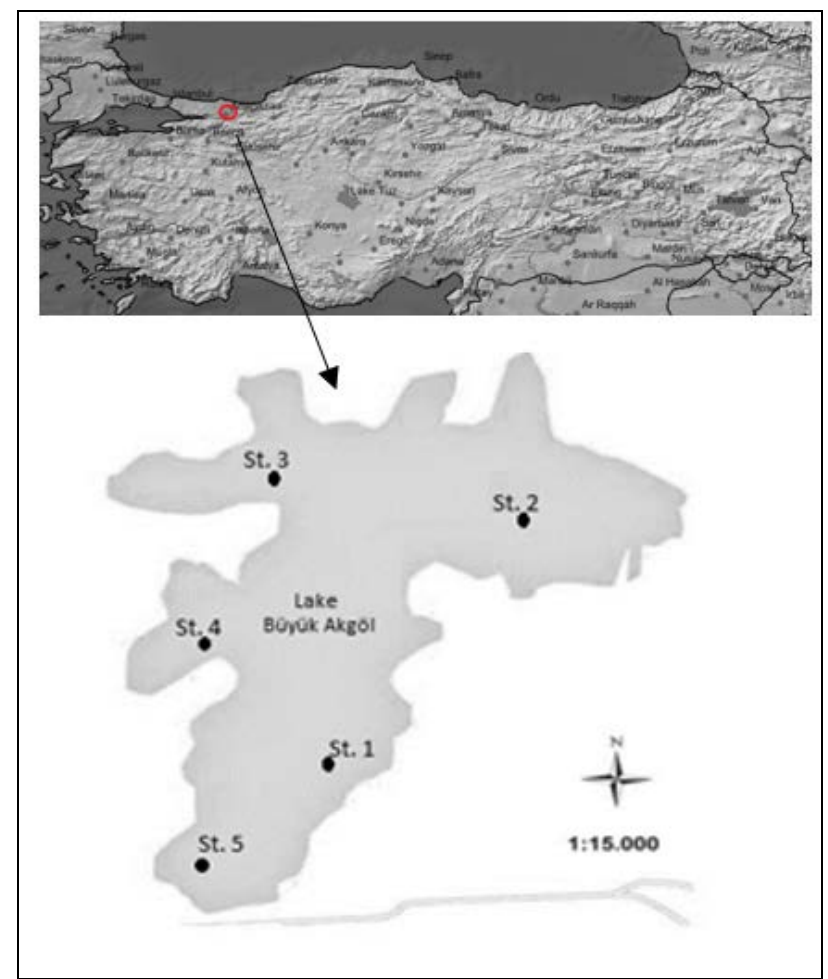

Figure 1: Map of the study area: sampling sites (St.1-5) in lake Büyük Akgöl, Turkey.

\section{Sampling procedures and data analysis}

Five sampling sites in lake Büyük Akgöl were studied in 2009, 2012 and 2014 years. The benthic macroinvertebrates were collected once a year, in the following months: September, October and September at different depths: three-six m, with an Ekman grab sampler. All collected samples were fixed immediately with 70\% ethyl alcohol.

At the laboratory, the collected macroinvertebrates were sorted and counted, by using a stereomicroscope and then identified to the lowest possible taxon (species, genus, family or order). The identification keys of Brinkhurst and Jamieson (1971), Şahin (1991), Nilsson and Holmen (1995), Papp and Darvas (1997), Papp and Darvas (1998), Boucherd (2004), and Birmingham (2005) were used for the benthic macroinvertebrate identification.

The following indices were calculated: relative abundance, dominance, ShannonWiener, Simpson, evenness, and Margalef. The average data per year were used in the calculations. 


\section{RESULTS}

The benthic macroinvertebrate fauna in lake Büyük Akgöl in the study period was represented by the following taxonomic groups: Gastropoda, Bivalvia, Oligochaeta, Chironomidae, Trichoptera, Ceratopogonidae, Ephemeroptera, Odonata, Chaoboridae, and Hirudinea. The taxa collected at the five sites in 2009, 2012 and 2014, and their relative abundance (in \%) are given in table 1.

Table 1: Benthic macroinvertebrate taxa in lake Büyük Akgöl, Turkey, and their relative abundance (in \%) in 2009, 2012 and 2014.

\begin{tabular}{|c|c|c|c|c|}
\hline $\begin{array}{l}\text { Main } \\
\text { taxonomic } \\
\text { group }\end{array}$ & Taxa & 2009 & 2012 & 2014 \\
\hline \multirow[t]{10}{*}{ Gastropoda } & $\begin{array}{l}\text { Planorbarius corneus } \\
\text { (Linnaeus, 1758) }\end{array}$ & 5.57 & 1.42 & 1.42 \\
\hline & $\begin{array}{l}\text { Lymnea stagnalis } \\
\text { (Linnaeus, 1758) }\end{array}$ & 12.80 & 11.67 & 12.28 \\
\hline & $\begin{array}{l}\text { Viviparus viviparus } \\
\text { (Linnaeus, 1758) }\end{array}$ & 16.85 & 16.43 & 16.73 \\
\hline & $\begin{array}{l}\text { Theodoxus fluviatilis } \\
\text { (Linnaeus, 1758) }\end{array}$ & 5.19 & 4.09 & 4.03 \\
\hline & Bithynia sp. & 1.18 & 1.18 & 0.00 \\
\hline & $\begin{array}{l}\text { Valvata piscinalis } \\
\text { (Müller, 1774) }\end{array}$ & 0.84 & 0.84 & 3.20 \\
\hline & $\begin{array}{l}\text { Borystenia naticina } \\
\text { (Menke, 1845) }\end{array}$ & 9.36 & 4.73 & 1.22 \\
\hline & Gyraulus sp. & 0.61 & 0.63 & 1.14 \\
\hline & $\begin{array}{l}\text { Physa acuta } \\
\text { Draparnaud, } 1805\end{array}$ & 0.50 & 0.32 & 2.40 \\
\hline & $\begin{array}{l}\text { Radix labiata } \\
\text { (Rossmassler, 1835) }\end{array}$ & 0.61 & 0.10 & 0.00 \\
\hline \multirow[t]{2}{*}{ Bivalvia } & $\begin{array}{l}\text { Dreissena polymorpha } \\
\text { (Pallas, 1771) }\end{array}$ & 19.60 & 32.40 & 34.80 \\
\hline & Bivalvia sp. & 7.35 & 5.80 & 1.03 \\
\hline \multirow[t]{7}{*}{ Oligochaeta } & $\begin{array}{l}\text { Potamothrix hammoniensis } \\
\text { (Michaelsen, 1901) }\end{array}$ & 8.37 & 9.17 & 10.03 \\
\hline & $\begin{array}{l}\text { Tubifex tubifex } \\
\text { (Müller, 1774) }\end{array}$ & 1.16 & 2.01 & 1.21 \\
\hline & $\begin{array}{l}\text { Limnodrillus hoffmeisteri } \\
\text { Claparède, } 1862\end{array}$ & 0.25 & 2.24 & 1.54 \\
\hline & $\begin{array}{l}\text { Potamothrix bedoti } \\
\text { (Piguet, 1913) }\end{array}$ & 0.49 & 0.12 & 1.20 \\
\hline & $\begin{array}{l}\text { Dero digitata } \\
\text { Müller, } 1773\end{array}$ & 0.31 & 0.31 & 0.31 \\
\hline & $\begin{array}{l}\text { Nais communis } \\
\text { Piguet, } 1906\end{array}$ & 0.68 & 0.42 & 0.31 \\
\hline & $\begin{array}{l}\text { Ophidonais serpentine } \\
\text { Müller, } 1773\end{array}$ & 0.86 & 1.03 & 1.03 \\
\hline
\end{tabular}


Table 1 (continued): Benthic macroinvertebrate taxa in lake Büyük Akgöl, Turkey, and their relative abundance (in \%) in 2009, 2012 and 2014.

\begin{tabular}{|c|c|c|c|c|}
\hline \multirow{3}{*}{$\begin{array}{c}\text { Main } \\
\text { taxonomic } \\
\text { group }\end{array}$} & Таха & 2009 & 2012 & 2014 \\
\hline & $\begin{array}{l}\text { Stylaria lacustris } \\
\text { (Linnaeus, 1767) }\end{array}$ & 0.01 & 0.01 & 0.52 \\
\hline & $\begin{array}{l}\text { Pristina aeguiseta } \\
\text { (Bourne, 1891) }\end{array}$ & 0.05 & 0.05 & 0.00 \\
\hline \multirow[t]{9}{*}{ Chironomidae } & $\begin{array}{l}\text { Procladius } \\
\text { (Holotanypus) sp. }\end{array}$ & 1.39 & 0.63 & 0.90 \\
\hline & $\begin{array}{l}\text { Fleuria lacustris } \\
\text { Kieffer, } 1924\end{array}$ & 0.22 & 0.12 & 0.17 \\
\hline & Zalutschia sp. & 0.01 & 0.01 & 0.09 \\
\hline & $\begin{array}{l}\text { Einfeldia pagana } \\
\text { (Meigen, 1838) }\end{array}$ & 0.94 & 0.25 & 0.93 \\
\hline & $\begin{array}{l}\text { Parachironomus swammerdami } \\
\text { (Kruseman, 1933) }\end{array}$ & 0.80 & 0.72 & 0.00 \\
\hline & $\begin{array}{l}\text { Chironomus plumosus } \\
\text { (Linnaeus, 1758) }\end{array}$ & 0.33 & 0.33 & 0.52 \\
\hline & $\begin{array}{l}\text { Chironomus (Camptoch) tentans } \\
\text { Fabricious, } 1805\end{array}$ & 1.27 & 2.03 & 2.45 \\
\hline & Monopsectrocladius sp. & 0.16 & 0.16 & 0.37 \\
\hline & $\begin{array}{l}\text { Dicrotendipes nervosus } \\
\text { (Staeger, 1839) }\end{array}$ & 0.84 & 0.28 & 0.00 \\
\hline \multirow[t]{7}{*}{ Others } & Trichoptera & 0.50 & 0.21 & 0.03 \\
\hline & Ceratopogonidae & 0.03 & 0.02 & 0.01 \\
\hline & Ephemeroptera & 0.22 & 0.04 & 0.03 \\
\hline & Odonata & 0.02 & 0.02 & 0.04 \\
\hline & Chaoboridae & 0.53 & 0.20 & 0.05 \\
\hline & Hirudinea & 0.12 & 0.01 & 0.01 \\
\hline & Total & 100.00 & 100.00 & 100.00 \\
\hline
\end{tabular}

In 2009, a total of 85 individuals, belonging to 36 taxa, were identified. The benthic macroinvertebrate fauna consisted of Gastropoda (53.4\%), Bivalvia (26.8\%), Oligochaeta (12.6\%), Chironomidae (5.9\%) and other taxonimic groups, including Trichoptera, Ceratopogonidae, Ephemeroptera, Odonata, Chaoboridae, and Hirudinea (1.04\%). The species with the highest relative abundance were as follow: Viviparus viviparus (16.85\%) and Lymnea stagnalis (12.8\%) from Gastropoda, Dreissena polymorpha (19.6\%) from Bivalvia, Potamothrix hammoniensis (8.37\%) from Oligochaeta, and Procladius (Holotanypus) sp. (1.39\%) and Chironomus (C.) tentans (1.27\%) from Chironomidae (Tab. 1). 
In 2012, 90 individuals, belonging to 36 taxa were identified, while in 2014, 92 individuals belonging to 28 taxa, were identified in the samples. The species with the highest relative abundance were the same: $V$. viviparus (16.43\% and $16.93 \%$, respectively), L. stagnalis ( $11.67 \%$ and $12.28 \%$, respectively), D. polymorpha $(32.40 \%$ and $34.80 \%$, respectively), $P$. hammoniensis (9.17\% and $10.03 \%$, respectively) and C. (Camptoch) tentans (2.03\% and 3.01\%, respectively) (Tab. 1). The results show that from 2009 to 2012, Bivalvia and Oligochaeta increased (38.2\% and $15.3 \%$ respectively), whereas the other taxonomic groups, in particular, Gastropoda and Chironomidae ( $41.4 \%$ and $4.5 \%$, respectively) were found to decrease. However, when considering the whole study period (2009-2014), the taxonomic groups of Gastropoda, Oligochaeta and Chironomidae increased, whereas the other taxonomic groups (Trichoptera, Ceratopoganidae, Ephemeroptera, Odonata, Chaoboridae, and Hirudinea) decreased (Fig. 4).

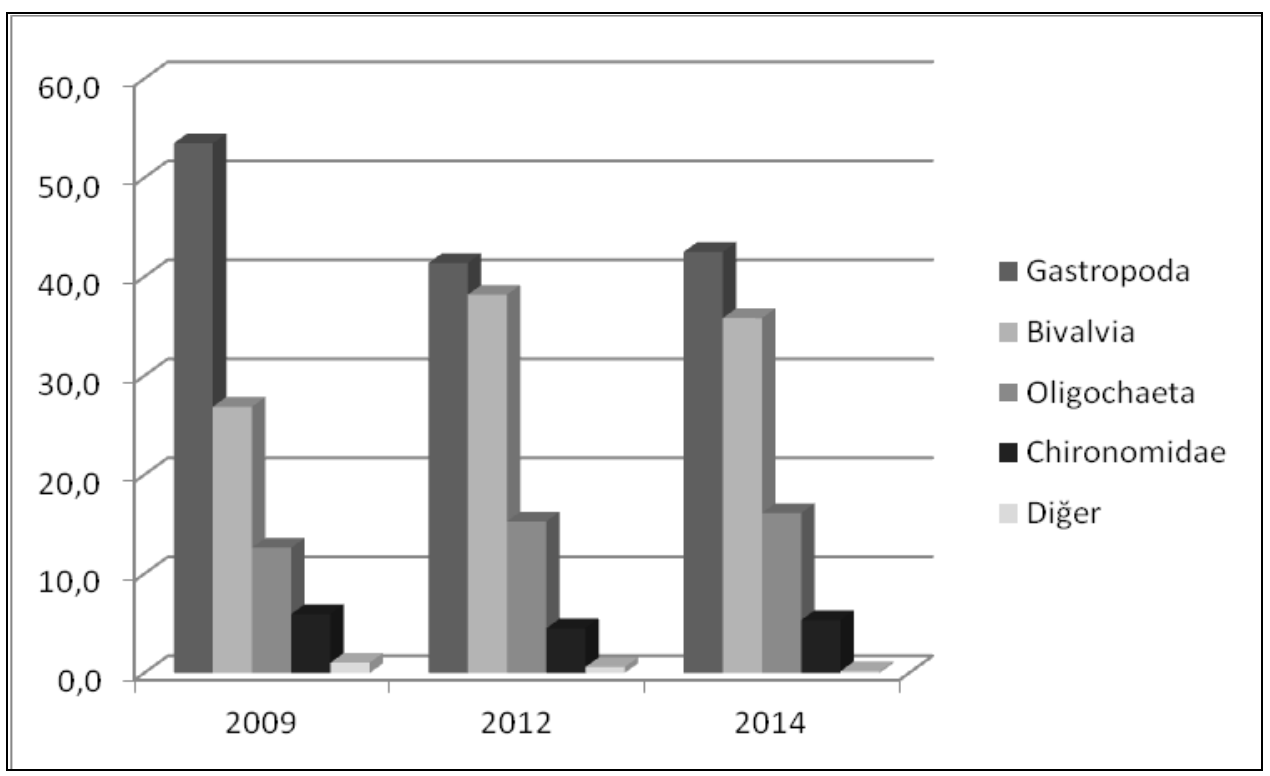

Figure 2: Relative abundance of the main taxonomic groups of benthic macroinvertebrates in lake Büyük Akgöl in 2009, 2012 and 2014.

The values of diversity indices (dominance, Shannon-Wiener, Simpson, evenness, and Margalef) for the three study years are given in table 2. The results show that the number of the identified taxa and the values of diversity indices from 2009 to 2014 decreased (Tab. 2).

Table 2: Values of diversity indices calculated on benthic macroinvertebrates in lake Büyük Akgöl, Turkey, in 2009, 2012 and 2014.

\begin{tabular}{|l|c|c|c|}
\hline \multicolumn{1}{|c|}{ Indices/Years } & 2009 & 2012 & 2014 \\
\hline Taxa & 36 & 36 & 31 \\
\hline Individuals & 85 & 90 & 91 \\
\hline Dominance & 0.1542 & 0.2016 & 0.217 \\
\hline Shannon-Wiener & $\mathbf{2 . 8 1}$ & $\mathbf{2 . 4 3 3}$ & $\mathbf{2 . 3 5 0}$ \\
\hline Simpson & 0.8458 & 0.7984 & 0.783 \\
\hline Evenness & 0.4612 & 0.3166 & 0.338 \\
\hline Margalef & 7.878 & 7.778 & 6.651 \\
\hline
\end{tabular}




\section{DISCUSSION}

In the current study, the relative abundance of the following taxa increased from 2009 to 2014: Valvata piscinalis, Gyraulus sp., and Physa acuta from Gastropoda, P. hammoniensis, Limnodrillus hoffmeisteri, Potamothrix bedoti, and Stylaria lacustris from Oligochaeta, and Chironomus plumosus and Ch. (C.) tentans from Chironomidae (Tab. 1). In the same period, the relative abundance of $D$. polymorpha increased twice. Most of these species are poly- and mesosaprobic species, tolerant to organic pollution (Hellawell, 1986). They are very common in the Turkish freshwaters (Yıldırım et al., 2006; Yıldız et al., 2007; Arslan et al., 2010). The genera Potamothrix, Limnodrilus and Stylaria are widely distributed throughout the world (Wetzel et al., 2000). P. hammoniensis, which is a freshwater euryhalin species (Grigelis, 1980), was the most abundant Oligochaeta species in the lake. Many species of the genus Chironomus are known as excellent indicators of organic pollution (Simpson and Bode, 1980), and the high density of Chironomus, shows eutrophic features of the environment (Tate and Heiny, 1995; Botts, 1997). Chironomus (Camptoch) tentans which was most abundant species from Chironomidae in this study is referred as being positive indicator of organic pollution (Arslan et al., 2010). Some certain molluscs' species are indicators of water quality (Oehlmann and Schulte-Oehlmann, 2002. Freshwater pulmonates have distributed world-wide and broad environmental tolerances (Strong et al., 2008). Griffiths et al. (1993) were reported that when Dreissena population increased, densities of gastropods generally increased. Most abundant species from Gastropoda were Lymnea stagnalis and Viviparus viviparus in studied years. When examined according to the increasing rate of Gastropoda species dominancy, Valvata piscinalis and Physa acuta were increased almost three times more (from $0.84 \%$ to $3.20 \%$ and from $0.50 \%$ to $2.40 \%$, respectively) whereas Borystenia naticina was decreased. According to results of our present study, in 2009, Valvata piscinalis and Physa acuta were of $0.008 \%$ and $0.005 \%$ of total zoobenthic community, respectively. In six years, these dominancy ratios were increased to $0.032 \%$ and $0.024 \%$, respectively. Although these two species populations have increased, this increase is still not a very high ration ratio in general zoobenthic fauna. Variation in population density of three gastropod species (Lymnea stagnalis, Viviparus viviparous and Borystenia naticina) can also be due to a negative change in water quality. However, since some water quality parameters couldn't have been measured in the present study, it is difficult to conclude that the population change of gastropoda species is due to water quality change and/or Dreissena population pressure.

Zebra mussels provide habitats altering the surface of substrate and providing spatial refuge and food for other benthic invertebrates. Besides providing shell-generated habitat to benthic macroinvertebrates, particulate organic matters produced by Dreissena are used by other macroinvertebrates as food and also increase their community (Karatayev et al., 2002; 2005). In the results of present study, density of some Chironomidae and Oligochaeta species were increased almost three times more. In the current study, dominancy of Chironomidae and Oligochaeta consisting of $0.12 \%$ and $0.059 \%$ of whole zoobenthic community in 2009 , respectively was observed. In 2014 , these dominancy values were changed to $0.16 \%$ and $0.054 \%$.

Wolnomiejski (1970) was studied with effect of Dreissena to benthic macroinvertebrate community reported that zebra mussels are used as substrate or shelter by many benthic taxa (including the isopod, larval chironomids and the leech). We agree with authors of previous studies. 
Community of benthic macroinvertebrates in the littoral areas of lakes and rivers increase (often doubling) by dreissenid colonization. Furthermore, zebra mussels have negative effect on particular taxonomic and functional groups (like densities of native bivalves) (Ward and Ricciardi, 2007). In the present study, when dominancy of D. polymorpha increased, other Bivalvia species with unidentified level of species were decreased almost six times.

Stewart et al. (1998) were reported that causing changes in biomass and densities of macroinvertebrate taxa by Dreissena altered macroinvertebrate community composition lead to changes in the relative abundance of other macroinvertebrates. Dominancy of chironomid Dicrotendipes decreased in the presence of Dreissena. Results of their study were showed that Dreissena had adverse effects on Dicrotendipes. As seen in table 1, Dicrotendipes nervosus and Parachironomus swammerdami from Chironomidae were detected in 2009, their population density decreased in 2012 and finally in 2014 these species were not found in the lake; however, total dominancy of Chironomidae were increased.

Zebra mussel biodeposition was assumed responsible for increased abundances of deposit feeding chironomids and oligochaetes in European lakes (Lyakhnovich et al., 1982; Smit et al., 1993). Griffiths (1993) suspected that population increases in Potamothrix moldaviensis and Spirosperma ferox in lake Saint Clair were resulted from deposition of feces and pseudofeces by Dreissena. Griffiths believed that increased densities of submerged vascular plants and benthic algae following colonization of lake Saint Clair by Dreissena contributed to the observed increase in macroinvertebrate populations. In our study, dominancy of Oligochaeta was increased from $12.6 \%$ to $16.15 \%$ (between the years 2009 2014) while dominancy of Dreissena was almost doubling. These results also showed that Dreissenia polymorpha had a positive effect on zoobenthic community structure at least in mesosaprob and oligosabrob taxa such as Oligochaeta and Chironomidae, as reported in previous studies (Wolnomiejski, 1970; Griffth, 1993).

Consequently, macroinvertebrate fauna of lake Büyük Akgöl is not diverse, but 30 species (10 species from Gastropoda, two species from Bivalvia, nine species from Oligochaeta and nine species from Chironomidae) were identified in the lake. Identified species (especially Potamothrix hammoniensis, Limnodrilus hoffmeisteri and Tubifex tubifex from Oligochaeta and Chironomus plumosus and Chironomus (Camptoch) tentans from Chironomidae) have especially broad ecological valence. Within six years, while dominancy of $D$. polymorpha was increased, the benthic macroinvertebrate community structure changed in terms of taxonomical composition and relative abundance of functional groups. Population density of some species which are Valvata piscinalis and Physa acuta from Gastropoda, Potamothrix hammoniensis, Limnodrillus hoffmeisteri, Potamothrix bedoti, Ophidonais serpentina and Stylaria lacustris from Oligochaeta, Zalutschia sp., C. plumosus, C. (Camptoch) tentans and Monopsectrocladius sp. from Chironomidae were increased. On the other side, some species which are Bithynia sp. and Radix labiata from Gastropoda, Pristina aeguiseta from Oligochaeta, Parachironomus swammerdami and Dicrotendipes nervosus from Chironomidae were not found in the lake. As can be caused this situation changes in environmental conditions, may be negative population effect of $D$. polymorpha on sensitive species.

It is clear that $D$. polymorpha has been dispersing different benthic habitat of lake Büyük Akgöl at least since the beginning of the study and is still invading. Present study results showed that when population density of $D$. polymorpha increases, benthic invertebrate communities change in terms of taxonomical composition and relative abundance of functional groups. 


\section{ACKNOWLEDGEMENTS}

The study was carried out under the project no. 109T076 by TUBITAK (The Scientific and Technological Research Council of Turkey) and partly under Project no. 201319A106, by Eskisehir Osmangazi University-BAP for determining zoobenthic fauna of lake Büyük Akgöl. In addition, authors thanks to Teodora Trichkova, Bulgarian Academy of Sciences, Institute of Zoology, for consultation. 


\section{REFERENCES}

1. Ackerman J. D., Loewen M. R. and Hamblin P. F., 2001 - Benthic-pelagic coupling over a Zebra Mussel reef in western lake Erie, Limnology and Oceanography, 46, 892-904.

2. Afanasiev S. A., 1987 - The differences in oligochaeta distribution in periphyton on substrate with different structure, 38-41, in Kachalova O. L. and Parele E. A. (eds), Water Oligochaeta, Transactions of the Six All-Union Symposium, Biological Institute of the Academy of Science Latvian SSR Press, Riga. (in Russian)

3. Aksu S., Yıldız D. and Güngör A. P., 2017 - How Zebra mussels threaten to water supply security and effects of preventive measures in Turkey, World Scientific News, 64, 99-126.

4. Anastasiu P., Preda C., Bănăduc D., and Cogălniceanu D., 2017 - Alien species of European Union concern in Romania, Transylvanian Review of Systematical and Ecological Research, volume 19.3, The Wetlands Diversity, 93-106, ISSN-L 1841 - 7051, ISSN 2344-3219.

5. Arslan N., Ayık Ö. and Şahin Y., 2010 - Diversity and structure of Chironomidae (Diptera) limnofauna of lake Uluabat, a Ramsar site of Turkey, and their relation to environmental variables, Turkish Journal of Fisheries and Aquatic Sciences, 10, 315-322.

6. Birmingham M., Heimdal D., Todd H., Ken K., Richard L., Jim W., Jacklyn N., Brian S. and Tom W., 2005 - Benthic macroinvertebrate key, Iowater volunteer water quality monitoring, http://www.iowater.net/

7. Botts P. S., 1997 - Spatial pattern, patch dynamics and successional change: chironomid assemblages in a lake Erie coastal wetland, Freshwater Biology, 37, 277-286.

8. Botts P. S., Patterson B. A. and Schloesser D. W., 1996 - Zebra mussel effects on benthic invertebrates: physical or biotic? Journal of North American Benthological Society, 15, 179-184.

9. Boucherd R. W. Jr., 2004 - Guide to aquatic invertebrates of the upper Midwest, Universtiy of Minnesota, ISBN-00511309763.

10. Brinkhurst R. O. and Jamieson B. G. M., 1971 - Aquatic Oligochaeta of the world, University of Toronto, 860.

11. Daniszewski P., 2015 - Total alkaline phosphatase activity (ALP-EC 3.1.3.1) of water in the river Odra estuary (North-West Poland), World News of Natural Sciences, 1, 1-10.

12. Daunys D., Zemlys P., Olenin S., Zaiko A. and Ferrarin C., 2006 - Impact of the Zebra mussel Dreissena polymorpha invasion on the budget of suspended material in a shallow lagoon ecosystem, Helgoland Marine Research, 60, 113-120.

13. Dermott R. and Munawar M., 1993 - Invasion of lake Erie offshore sediments by Dreissena, and its ecological implications, Canadian Journal of Fisheries and Aquatic Sciences, 50, 2298-2304.

14. Draszawka-Bołzan B. and Cyraniak E., 2015 - Quality monitoring of marine coastal waters in Poland, World News of Natural Sciences, 1, 11-18.

15. DSİ, 2005 - Hidroelektrik santrallarda sorun zaratan Zebra midye araştırmaları raporu, DSİ Genel Müdürlüğü İşletme ve Bakım Dairesi Başkanlığı, Ankara, Türkiye. (in Turkish)

16. Dusoge K., 1966 - Composition and interrelations between macrofauna living on stones in the littoral of Mikolajskie Lake, Ekologia Polska Seria A, 14, 755-762.

17. Geldiay R. and Bilgin F. H., 1973 - Batı anadolu'nun bazı tatlı sularında yaşayan bir bivalv türü "Dreissena polymorpha” (Pallas) Hakkında, Ege Üniversitesi İlmi Raporlar Serisi, 158, 1973, Ege Üniversitesi Matbaası, Bornova. (in Turkish)

18. Griffiths C. L., Hockey P. A. R., van Erkom Schurink C. and Le Roux P. J., 1992 - Marine invasive aliens on South African shores: implications for community structure and trophic functioning, South African, Journal of Marine Science, 12, 713-722.

19. Griffiths R. W., 1993 - Effects of Zebra mussels (D. polymorpha) on the benthic fauna of lake St. Clair, in Zebra mussels: biology, impacts, and control, Lewis Publishers, Boca Raton, FL, 415-437.

20. Grigelis A., 1980 - Ecological studies of aquatic Oligochaetes in the USSR, in Brinkhurst R. O. and Cook D. G. (eds), Aquatic Oligochaeta Biology, Plenum Press, New York, 225-240.

21. Hellawell J. M., 1986 - Biological indicators of freshwater pollution and environmental management, Elsevier, London, 452-508. 
22. Hulme P. E., 2009 - Delivering alien invasive species inventories for Europe (DAISE) Handbook of alien species in Europe, Springer, New York.

23. Karatayev A. Y., Burlakova L. E. and Padilla D. K., 2005 - Contrasting distribution and impacts of two freshwater exotic suspension feeders, Dreissena polymorpha and Corbicula fluminea, in Dame R. and Olenin S. (eds), The comparative roles of suspension feeders in ecosystems, NATO Science Series IV: earth and environmental sciences, 47, Netherlands, Springer, 239-262.

24. Karayayev A., Burlakova L. E. and Padilla D. K., 2002 - Impacts of Zebra mussels on aquatic communities and their role as ecosystem engineers, 433-446, in Leppakoski E., Gollasch S. and Olenin S. (eds), Invasive Aquatic Species of Europe: Distribution, Impacts and Management, Springer, Dordrecht, Netherlands.

25. Kharchenko T. G. and Protasov A. A., 1981 - On consortia in water ecosystems, Gidrobiol, 17, 15-20. (in Russian)

26. Luque G. M., Bellard C., Bertelsmeier C., Bonnaud E., Genovesi P., Simberloff D. and Courchamp F., 2013 - The 100th of the world' worst invasive alien species, Biological invasions, DOI: 10.1007/s10530-013-0561-5.

27. Lyakhnovich U. P., Gavrilov S. I., Karataev A. Y., Karataeva I. V. and Myakhaeva T. I., 1982 Long-term changes in the macrobenthos of the Lukoml'skoe Lake, Vyestsi Akad, Navuk, BSSR Syer Biyal, Navak, 1982, 91-93, (Translated from Russian by New York Sea Grant Extension, Brockport, NY).

28. Minchin D. and Zaiko A., 2013 - Variability of the Zebra mussel (Dreissena polymorpha) impacts in the Shannon River system, in Quagga and Zebra Mussels: Biology, Impacts and Control, Nalepa T. F. and Schlosser D. W. (eds), CRC Press, Taylor and Francis Group: Boca Raton, FL, 587-597.

29. Nilsson A. N. and Holmen M., 1995 - The Aquatic Adephaga (Coleoptera) of Fennoscandia and Denmark, II, Dytiscidae, Fauna Entomologica Scandinavica, 32, Brill E. J., Leiden, 192 s.

30. Oehlman J. and Schulte-Oehlman U., 2002 - Molluscs as bioindicator, chapter 17, (eds) Markert B. A., Breure A. M. and Zechmeister H. G., Bioindicators and Biomonitors, 577-635.

31. Papp L. and Darvas B., 1997 (eds) - Contributions to a manual of Palaearctic Diptera, 2, Nematocera and lower Brachycera, Science Herald, Place, 592.

32. Papp L. and Darvas B., 1998 - Contributions to a manual of Palearctic Diptera, 3, higher Brachycera, Science herald, Budapest, ISBN 963048838 8, 880s.

33. Pimentel D., Lach L., Zuniga R. and Morrison D., 2000 - Environmental and economic costs associated with non-indigenous species in the United States, BioScience, 50, 1, 53-65.

34. Pollux B. J. A., Minchin D., Van der Velde G., Van Alen T., Moon-Van der Staay S. and Hackstein J. H. P., 2003 - Zebra mussels (Dreissena polymorpha) in Ireland, AFLP fingerprinting and boat traffic both indicate an origin from Britain, Freshwater Biology, 48, 1127-1139.

35. Quinn A., Gallardo B. and Aldridge C. D., 2013 - Quantifying the ecological niche overlap between two interacting invasive species: the Zebra mussel (Dreissena polymorpha) and the Quagga mussel (Dreissena rostriformis bugensis), Aquatic Conservation: Marıne And Freshwater Ecosystems (2013) Published online in Wiley Online Library (wileyonlinelibrary.com), DOI: 10.1002/aqc.2414.

36. Ricciardi A. and Rasmussen J. B., 1999 - Extinction Rates of North American Freshwater Fauna, Conservation Biology, 13, 1220-1222.

37. Simpson K. W. and Bode R. W., 1980 - Common larvae of Chironomidae (Diptera) from New York State streams and rivers with particular reference to the fauna of artificial substrates, Bulletin 439 of the New York State Museum, Albany, 105.

38. Smit H., Bij de Vaate A., Reeders H. H., van Nes E. H. and Noordhuis R., 1993 - Colonization, ecology, and positive aspects of Zebra mussels (Dreissena polymorpha) in the Netherlands, in Zebra mussels: biology, impacts, and control, Nalepa T. F. and Schloesser D. W. (eds), Lewis Publishers, Boca Raton, Fla., 55-77. 
39. Stewart T. W. and Haynes J. M., 1994 - Benthic macroinvertebrate communities of southwestern lake Ontario following invasion of Dreissena, Jurnal of Great Lakes Research, 20, 479-493.

40. Stewart T. W., Miner J. G. and Lowe R. L., 1998 -Quantifying mechanisms for Zebra mussel effects on benthic macroinvertebrates: organic matter production and shellgenerated habitat, Journal of North American Benthological Society, 17, 81-94.

41. Strong E. E., Gargominy O., Winston F. P. and Bouchet P., 2008 - Global diversity of gastropods (Gastropoda; Mollusca), in freshwater, Hydrobiologia, 595, 149-166.

42. Stuckey R. L. and Moore D. L., 1995 - Return and increase in abundance of aquatic flowering plants in Put-in-Bay Harbor, Lake Erie, Ohio, Ohio Journal of Science, 95, 261-266.

43. Şahin Y., 1991 - Türkiye chironomidae potamofaunası (Chironomidae Potamofauna of Turkey), Tubitak, project no. TBAG-869, VHAG-347, TBAG-669, TBAG-79, 88 s. (in Turkish)

44. Tate C. M. and Heiny S. J., 1995 - The ordination of benthic invertebrate communities in the South Platte Basin in relation to environmental factors, Freshwater Biology, 33, 439-454

45. Yıldırım M. Z., Gümüş B. A., Kebapçı Ü. and Bahadır-Koca S., 2006 - The Basommatophoran pulmonate species (Mollusca: Gastropoda) of Turkey, Turkish Journal of Zoology, 30, 445-458.

46. Yıldız S., Ustaoğlu M. R. and Balık S., 2007 - The Oligochaeta (Annelida) fauna of Yuvarlak Stream (Köyceğiz-Turkey), Turkish Journal of Fisheries and Aquatic Sciences, 7, 01-06.

47. Ward J. M. and Ricciardi A., 2007 - Impacts of Dreissena invasions on benthic macroinvertebrate communities: A meta-analysis, Diversity Distribution, 13, 155-165.

48. Wetzel M. J., Kathman R. D., Fend S. and Coates K. A., 2000 - Taxonomy, systematic and ecology of freshwater Oligochaeta, Workbook prepared for North American Benthological Society technical information Workshop, 48th Annual Meeting, Keystone Resort, CO., 120.

49. Wilas J., Draszawka-Bołzan B. and Cyraniak E., 2016 - Wastewater reuse, World News of Natural Sciences, 5, 33-43.

50. Wolnomiejski N., 1970 - The Effects of Dreissena polymorpha Pall., Aggregation on the differentiation of the benthonic macrofauna, Zecz nauk UMK, 25, 31-39. 